\title{
Potret Patologi Birokrasi Di Kantor Badan Pertanahan Nasional Agraria dan Tata Ruang (BPN-ATR), Kota Cimahi
}

\author{
Hamirul \\ Sekolah Tinggi Ilmu Administrasi Setih Setio Muara Bungo \\ Jambi,Indonesia \\ Email: hrul@ymail.com
}

Received: 30 Juli 2019; Revised: 02 Februari 2020; Accepted: 12 Februari 2020

\begin{abstract}
The problem of bureaucracy has become a national problem, not least in the city of Cimahi, BPN / ATR as one of the institutions serving the community has always been in the spotlight because of the many complaints felt by the community and in this paper the researcher wants to know the types of bureaucratic pathology that violate legal norms and laws. invitations that apply and what strategies can be done to overcome the problem. The method used is a mixed method with descriptive analysis, data collection techniques used are structured interviews and questionnaires. Pathology suffered by the BPN / ATR city of Cimahi; Receive a bribe, Corruption. The strategy carried out is the strategy of strengthening the role of individual bureaucracy related to the quality of human resources, the strategy of strengthening the role of the bureaucracy in an organization, and the Strengthening Strategy of the role of the bureaucracy in a systematic manner.
\end{abstract}

Keyword: Pathology; Bureaucratic; Legal Norms

\begin{abstract}
Abstrak
Permasalahan Birokrasi sudah menjadi masalah nasional, tidak terkecuali di kota Cimahi, BPN/ATR sebagai salah satu lembaga yang melayani masyarakat selalu menjadi sorotan kerena banyaknya keluhan yang dirasakan oleh masyarakat dan dalam tulisan ini peneliti ingin mengetahui jenis patologi birokrasi yang melanggar norma hukum dan perundang-undangan yang berlaku serta strategi apa saja yang dapat dilakukan untuk mengatasi masalah tersebut. Metode yang digunakan adalah mixed method dengan analisis deskriptif, Teknik pengumpulan data yang digunakan adalah wawancara terstruktur dan angket. Patologi yang di derita oleh BPN/ATR kota Cimahi; Menerima sogok, Korupsi. Strategi yang dilakukan adalah stretegi penguatan peran birokrasi secara individu terkait dengan kualitas SDM, Strategi penguatan peran birokrasi secara organisasi, dan Strategi Penguatan peran birokrasi secara kesisteman.
\end{abstract}

Kata Kunci:Patologi; Birokrasi; Norma Hukum 


\section{Available Online at http://journal.umgo.ac.id/index.php/Publik}

Publik (Jurnal Ilmu Administrasi) Vol 8 (2), December 2019

\section{PENDAHULUAN}

Banyak penelitian yang membahas Patologi Biorkrasi, namun pada tulisan ini Patologi Birokrasi yang dibahas lebih spesifik pada pelanggaran Norma Hukum dan perundang-undangan yang berlaku, dimana lokus pada penelitian ini di BPN/ ATR kota Cimahi. Patologi Birokrasi dalam pelayanan publik menjadi hal yang sangat penting dalam hal kajian pelayanan publik dimana masyarakat pengguna dimana Birokrasi tidak pernah lepas dari permasalahan sama seperti waktu terdahulu, saat ini baik pemerintah pusat maupun darah telah menghabiskan anggaran yang tidak sedikit untuk memperbaiki kinerja birokrasi yang ada sehingga penyakit birokrasi dalam pemerintahan ini harus diminimalisir sehingga kepuasaan untuk masyarakat dapat tercapai. Pemerintah mempunyai peranan yang sangat besar untuk pemenuhan kebutuhan dan kesejahteraan masyarakat dimana salah satu wujudnya adalah pelayanan publik (Anggraini, 2014).

Rendahnya komitmen pemerintah dalam hal penyelenggaraan pelayanan publik yang berkualitas dan rentan terhadap tindakan korupsi, menurunkan kepercayaan masyarakat kepada negara, dimana dikalangan birokrasi sendiri seakan sudah menjadi darah daging dengan berbagai macam perilaku yang akan menjadi benih dari tindakan pidana korupsi yang besar dimana mental korup seakan sudah menjadi patologi birokrasi dan susah untuk disembuhkan. Nepotisme masih menjadi masalah patologi birorasi dibeberapa daerah ( Usman, 2016). Tujuan yang diharapkan dalam perubahan secara signifikan atau rangkaian kegiatan pembaharuan secara konseptual, sistematis dan berkelanjutan dengan melakukan penataan,peninjauan dan pembaharuan system, kebijakan dan peraturan perundang-undangan aparatur negara termasuk moral aparatur negara serta memantapkan komitmen melaksanakan ketentuan peraturan perundang-undangan (Ulhak, 2017). Komitmen tersebut dapat meningkatkan profesionalisme dari aparatur biorkrasi tersebut yang indikatornya meliputi: kemahiran, kesiapan, tanggung jawab, disiplin menjadi komponen penting dalam mengatasi patologi birokrasi ( Hamirul, H, dkk 2018)

Berdasarkan hal tersebut di atas, maka Siagian Dalam Hamirul.H (2017), mengidentifikasi berbagai patologi birokrasi yang dikategorikan ke dalam lima kelompok, yaitu:

1) Patologi yang timbul karena persepsi dan gaya manajerial para pejabat di lingkungan birokrasi.

2) Patologi yang disebabkan karena kurangnya atau rendahnya pengetahuan dan keterampilan para petugas pelaksana berbagai kegiatan operasional.

3) Patologi yang timbul karena tindakan para aparat birokrasi yang melanggar norma-norma hukum dan peraturan perundang-undangan yang berlaku.

4) Patologi yang dimanifestasikan dalam perilaku para birokrat yang bersifat disfungsional.

5) Patologi yang merupakan akibat situasi internal dalam berbagai instansi dalam lingkungan pemerintahan.

Hamirul,.H (2017) Menyatakan bahwa patologi yang dimanifestasikan dalam perilaku yang bersifat disfungsional antara lain: Tidak disiplin, berpura-pura sibuk; bersekongkol berkerjasama dengan calo; adanya arogansi dari birokrasi sehingga perlu adanya peraturan yang jelas serta diterapkannya reward bagi keberhasilan birokrat dan perlunya 
pemberian hukuman agar dapat terkontrol dan kegiatan yang bersifat negatif tidak terulang.

Beberapa hal yang terjadi diatas dapat diatasi dengan cara menghilankang citra negatif menurut pandangan Yunus (2002), beberapa cara yang ditempuh untuk dapat menghilangkan citra negatif tersebut yang diharapkan dapat berkembang citra yang positif, antara lain; Mendorong proses demokrasi dalam masyarakat, antara lain dalam bentuk peningkatan pengawasan sosial agar menyimpang oleh anggota birokrasi semakin berkurang; Mengurangi campur birokrasi dalam berbagai kegiatan-kegiatan dalam masyarakat yang semakin maju, merupakan" porsi" masyarakat untuk menyelenggarakannya; Menggunakan setiap kesempatan untuk menumbuhkan persepsi mengenai pentingnya orientasi pelayanan, bukan orientasi kekuasaan dalam berfikir dan bertindak; Mengharuskan para pejabat tinggi membuat pernyataan kekayaan pada waktu mulai menjabat dan Laporan Akuntabilitas sebagai indikator kinerja pemerintah sangat penting menurut Hamirul. H (2019) dalam rangka mencegah Patologi Biorkrasi.

Selain beberapa hal diatas dapat mengubah citra birokrasi, namun terkadang budaya kerja birokarasi menjadi permasalahan tersendiri dan menurut Rivai (2013), bahwa pengembangan budaya baru bagi pegawai yang sesuai dengan Visi dan Misi organisasi sebagai agen pelayanan publiK tentu harus dilakukan. Orientasi pada kekuasaan yang sangat kuat selama ini telah mengusur orientasi pada pelayanan. Budaya dan etika pelayanan lama sulit berkembang dalam birokrasi karena para pegawai lebih menempatkan diri sebagai penguasa dari pada menjadi pelayan bagi warga dan masyarakat. dilayani oleh masyarakat oleh sebab itu tradisi pelayanan harus dirubah. Agar kualitas pelayanan pemerintah kepada publik akan meningkat seiring iklim kompetetif yang telah bergulir (Haryanto, 2007)

Pelayanan publik saat ini mengalami perubahan yang sangat signifikan dimana masyarakat sudah sangat kritis terhadap pelayanan yang diberikan oleh pemerintah dan di era 4.0 ini menurut Hamirul,.H (2018) penggunaan teknologi yang tinggi dan proses transparansi dalam pelayanan publik beberapa patologi yang diderita oleh institusi pemerintah dalam melayani masyarakat publik akan dapat diminimalisir. Hal ini harus sejalan dengan berkembangnya pengetahuan masyarakat dalam menggunakan dan mengakses informasi yang semakin cepat melalui teknologi 'yang digunakan dan hampir semua pelayanan yang diberikan oleh pemerintah sekarang sudah sangat muda di akses oleh seluruh masyarakat pengguna jasa yang dibutuhkan. Ardiyanto (2007) menjelaskan Manfaat e-government dalam pelayanan publik antara lain:

1. Memperbaiki kualitas pelayanan pemerintah kepada para stakeholder-nya (masyarakat, kalangan usahawan, dan industri), terutama dalam hal kinerja efektivitas dan efisiensi diberbagai kehidupan bernegara;

2. Meningkatkan transparansi, kontrol, dan akuntabilitas penyelenggaraan pemerintahan dalam rangka penerapan konsep good corporate governance.

3. Mengurangi secara signifikan total biaya administrasi, relasi dan interaksi yang dikeluarkan pemerintah maupun stakeholdernya untuk keperluan aktivitas sehari-hari. 
4. Memberikan peluang pemerintah untuk mendapatkan sumbersumber pendapatan yang baru melalui interaksinya dengan pihak-pihak yang berkepentingan.

5. Menciptakan suatu lingkungan baru yang dapat menjawab berbagai permasalahan yang dihadapi secara cepat dan tepat sejalan dengan perubahan global dan trend yang ada.

6. Memberdayakan masyarakat dan pihak-pihak yang lain sebagai mitra pemerintah dalam proses pengambilan kebijakan publik secara merata dan demokratis.

Dengan penggunaan Teknologi Informasi semua akses dalam hal transparansi atas penggunaan Dana Desa dan terutama tentang anggaran dapat diminimalisir (Hamirul, H, 2019)

\section{METODE PENELITIAN}

Strategi penelitian yang digunakan adalah Triangulasi konkuren. Menurut Creswell (2010) Strategi Triangulasi konkuren melibatkan pengumpulan data kuantitatif secara bersamaan pada tahap penelitian, kemudian membandingkan antara data kualitatif dengan data kuantitatif untuk mengetahui perbedaan atau kombinasi dan model analisa yang digunakan pada penelitian kuantitatif mengguakan deskriptif dan pada analisis kualitatifnya menggunakan teori pada fenomena kontemporer (masa kini) di dalam konteks kehidupan nyata. Berkaitan dengan fenomena yang akan diteliti, yaitu "Patologi Birokrasi Melanggar Norma Hukum dan Perundang-undangan yang berlaku", maka strategi penelitian Triangulasi konkuren dianggap cocok untuk digunakan.

\section{HASIL DAN PEMBAHASAN}

Pada hasil dan pembahasan ini yang akan dikaji adalah dimensi Patologi yang timbul karena tindakan para aparat birokrasi yang melanggar norma-norma hukum dan peraturan perundang-undangan yang berlaku dan masing-masing indikator di uji menggunakan instrument angket kemudian di uji validitas dan reliabilitasnya.

\section{Karakteristik patologi yang timbul karena tindakan para anggota birokrasi yang melanggar norma-norma hukum dan peraturan perundang-undangan yang berlaku}

Karekteristik ini adalah merupakan salah satu karakteristik dari patologi birokrasi, karakteristik jenis ini diwakili oleh 10 item pernyataan. Berdasarkan hasil pengumpulan data yang mengacu pada kuesioner, diperoleh rentang skor rentang nilai data untuk karakteristik patologi yang timbul karena tindakan para anggota birokrasi yang timbul karena tindakan para anggota birokrasi yang melanggar normanorma hukum dan peraturan perundangundangan yang berlaku diwakili 10 item pertanyaan untuk 42 responden. Rentang nilai diperoleh data perkalian antara jumlah responden dengan 10 item pernyataan dan selanjutnya dikalikan dengan skor alternatif jawaban, sehingga diperoleh skor rentang nilai jawaban maksimum ( $R_{\text {maks }}=$ 2100) dan nilai jawaban minimum $\left(R_{\min }=\right.$ 420) sebagai berikut:

42 responden $\times 10$ item x $5=2100$

42 responden $\times 10$ item $\times 4=1680$

42 responden $\times 10$ item $\times 3=1260$

42 responden $\times 10$ item $\times 2=840$

42 responden $\times 10$ item $\times 1=420$ 
Tabel 1. Hasil uji validitas patologi yang timbul karena tindakan para anggota birokrasi yang melanggar norma-norma hukum dan perundang-undangan yang berlaku.

\begin{tabular}{cccc}
\hline Item & $\mathrm{R}$ & $\mathrm{r}$ tabel & Keputusan \\
\hline 39 & 0,573 & 0,304 & Valid \\
40 & 0,707 & 0,304 & Valid \\
41 & 0,770 & 0,304 & Valid \\
42 & 0,548 & 0,304 & Valid \\
43 & 0,786 & 0,304 & Valid \\
44 & 0,780 & 0,304 & Valid \\
45 & 0,732 & 0,304 & Valid \\
46 & 0,762 & 0,304 & Valid \\
47 & 0,765 & 0,3040 & Valid \\
48 & 0,800 & 0,304 & Valid \\
\hline
\end{tabular}

Sumber: Hasil Pengolahan data, (2017)

Tabel 2. Hasil Uji Reliabilitas Instrumen Penelitian

\begin{tabular}{llccl}
\hline NO & \multicolumn{1}{c}{ Variabel penelitian } & Reliabilitas & $*)$ Rujukan & \multicolumn{1}{c}{ Keputusan } \\
\hline & Patologi yang timbul karena & 0.920 & $+0.90-1.00$ & Luar Biasa \\
tindakan para anggota & & & Reliabel \\
birokrasi yang melanggar & & & \\
& norma-norma hukum dan & & \\
peraturan perundang- & & & \\
& undangan yang berlaku $\left(\mathrm{X}_{3}\right)$ & & & \\
\hline
\end{tabular}

Sumber: Hasil Pengolahan Data, (2017)

Tabel 3 menunjukkan perkalian antara jumlah jawaban responden untuk masing-masing item pernyataan yang memiliki alternatif jawaban Sangat Setuju (SS), Setuju (S), Netral (N), Tidak Setuju (TS), Sangat Tidak Setuju (STS) dengan nilai alternatif jawaban mengacu pada skor jawaban untuk item pernyataan yang positif dan negatif. Semua pernyataan untuk karakteristik ini menggunakan alternatif jawaban yang positif. Pada kolom akhir diperoleh jumlah perkalian antara jumlah responden yang menjawab masing-masing alternatif jawaban dengan skor item pernyataan dan penjumlahannya menghasilkan total kecenderungan jawaban untuk karakteristik patologi yang timbul karena tindakan para anggota birokrasi yang melanggar norma-norma dan peraturan perundang-undangan yang berlaku, yaitu sebesar $\sum$ fi.xi $=1655$. Copyright () 2019, Publik (Jurnal Ilmu Administrasi), ISSN: 2301-573X (Print), ISSN: 2581-2084 (Online) 
Tabel 3.Skor nilai untuk karakteristik patologi yang timbul karena tindakan para anggota birokrasi yang melanggar norma-norma hukum dan peraturan perundangundangan.

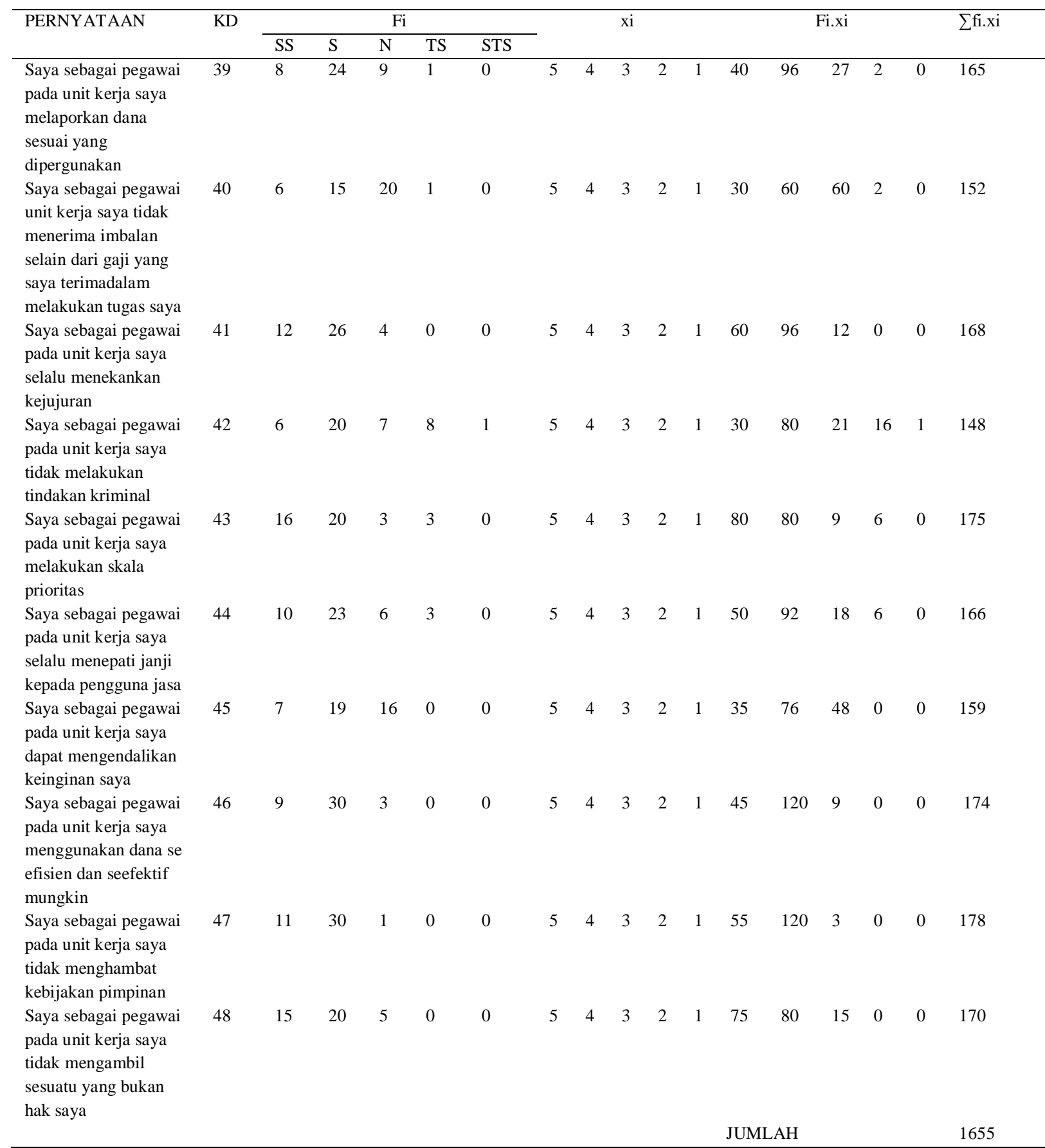

Sumber: data hasil penelitian diolah, (2017)

Rentang nilai pada hasil penelitian ini skor minimum dan skor maksimum jawaban responden yang telah dijelaskan diatas. Perhitungan pada tabel yang menghasilkan total nilai skor $\sum$ fi.xi $=445$ digambarkan pada gambar 1. Pada Gambar dijelaskan bahwa rentang nilai jawaban respon untuk karakteristik ini berada pada rentang jawaban sangat rendah menuju rendah $(\mathrm{SR}-\mathrm{R})=445$, sehingga dapat dikatakan bahwa karakteristik jenis ini sangat rendah terjadi di lingkungan kantor pertanahan Kota Cimahi.

menunjukkan bahwa posisi kecenderungan 


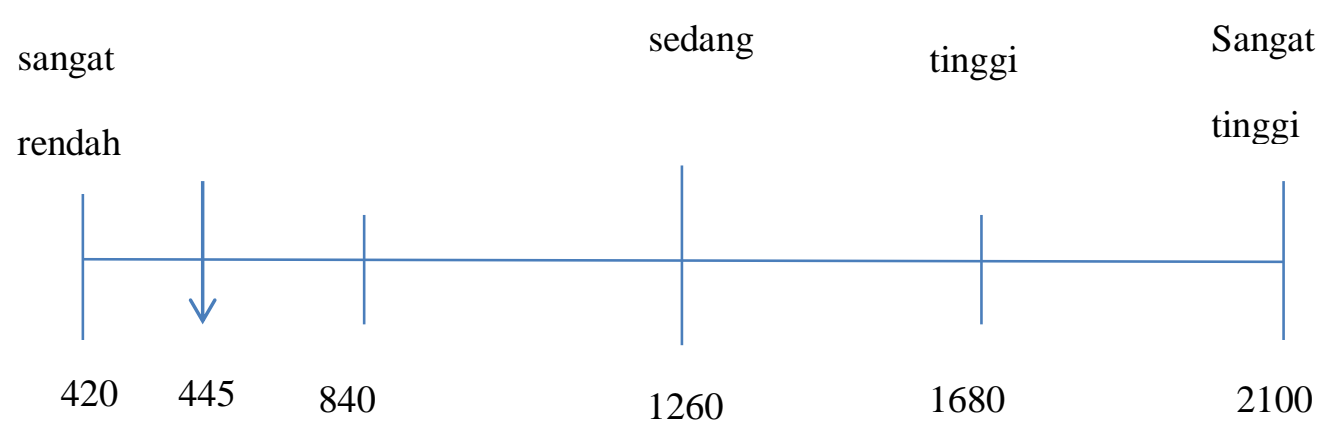

\section{Gambar 1.Rentang nilai untuk karakteristik patologi yang timbul karena tindak para anggota birokrasi yang melanggar norma-norma hukum dan peraturan perundang- undangan yang berlaku}

Berdasarkan hasil penggumpulan data yang mengacu pada kuesioner, diperoleh persentasi nilai data untuk karakteristik diatas yang diwakili oleh 10 item pernyataan untuk 42 responden dapat dilihat ditabel 4. Tabel 4 memperlihatkan $19,1 \%$ responden pegawai sangat setuju akan pernyataan yang menyatakan bahwa sebagai pegawai melaporkan dana sesuai yang digunakan dan $57,1 \%$ responden pegawai menyatakan setuju terhadap pernyataan tersebut hal ini berarti bahwa pegawai dilingkungan kantor pertanahan kota Cimahi dalam menggunakan dana sesuai dengan yang dibutuhkan, sedangkan $21,4 \%$ responden pegawai menyatakan sikap netral terhadap pernyataan tersebut dan $2,4 \%$ menyatakan tidak setuju yang berarti masih ada pegawai yang melaporkan penggunaan biaya yang digunakan tidak sesuai dengan kebutuhan atau dalam hal ini terjadi penggemukan biaya yang dilakukan oleh pegawai dilingkungan kantor pertanahan kota Cimahi.

Selanjutnya $14,3 \%$ responden pegawai sangat setuju akan pernyataan yang menyatakan bahwa pegawai tidak menerima imbalan selain gaji yang diterima dalam tugas dan $35,7 \%$ responden pegawai setuju akan hal tersebut, selanjutnya $47,6 \%$ responden pegawai menyatakan sikap netral dan 2,4\% responden pegawai menyatakan tidak setuju yang dalam hal ini berarti masih ada pegawai dilingkungan kantor pertanahan kota Cimahi yang masih menerima sogok dalam rangka penyelesaian pekeraan supaya lebih cepat dalam pelayanan.

Pernyataan pegawai selalu menekankan kejujuran 28,6\% responden pegawai menyatakan sangat setuju dan $61,9 \%$ menyatakan setuju dan berarti pegawai dilingkungan kantor pertanahan kota Cimahi masih menekankan kejujuran dalam hal menyelesaikan pekerjaan yang diminta oleh pengguna jasa, namun 9,5\% responden pegawai menyatakan sikap netral, yang berarti masih ada pegawai dilingkungan kantor pertanahan kota Cimahi terkadang tidak jujur dalam melayani masyarakat pengguna jasa, baik dalam hal waktu maupun biaya. Berikutnya $14,3 \%$ responden pegawai menyatakan sikap sangat setuju pada pernyataan bahwa pegawai selalu melaporkan kekayaan dan 47,6\% responden pegawai menyatakan sikap setuju, hal ini berarti pegawai dilingkungan kantor pertanahan kota Cimahi sudah transparan tentang kekayaan yang mereka miliki dan tentunya dapat mencegah tindakan korupsi. 
Tabel 4. Distribusi frekuensi untuk karakteristik patologi yang timbul karena tindakan para anggota birokrasi yang melanggar norma-norma hukum dan peraturan perundang-undangan yang berlaku

\begin{tabular}{|c|c|c|c|c|c|c|c|c|c|c|c|}
\hline \multirow[t]{2}{*}{ PERNYATAAN } & \multirow[t]{2}{*}{$\mathrm{KD}$} & \multicolumn{5}{|c|}{$\mathrm{Fi}$} & \multirow{2}{*}{\multicolumn{5}{|c|}{$\begin{array}{c}\text { Persen } \\
(\%)\end{array}$}} \\
\hline & & SS & $\mathrm{S}$ & $\mathrm{N}$ & TS & STS & & & & & \\
\hline $\begin{array}{l}\text { Saya sebagai pegawai } \\
\text { pada unit kerja saya } \\
\text { melaporkan dana } \\
\text { sesuai yang } \\
\text { dipergunakan }\end{array}$ & 39 & 8 & 24 & 9 & 1 & 0 & 19,1 & 57,1 & 21,4 & 2,4 & 0,0 \\
\hline $\begin{array}{l}\text { Saya sebagai pegawai } \\
\text { unit kerja saya tidak } \\
\text { menerima imbalan } \\
\text { selain dari gaji yang } \\
\text { saya terimadalam } \\
\text { melakukan tugas saya }\end{array}$ & 40 & 6 & 15 & 20 & 1 & 0 & 14,3 & 35,7 & 47,6 & 2,4 & 0,0 \\
\hline $\begin{array}{l}\text { Saya sebagai pegawai } \\
\text { pada unit kerja saya } \\
\text { selalu menekankan } \\
\text { kejujuran }\end{array}$ & 41 & 12 & 26 & 4 & 0 & 0 & 28,6 & 61,9 & 9,5 & 0,0 & 0,0 \\
\hline $\begin{array}{l}\text { Saya sebagai pegawai } \\
\text { pada unit kerja saya } \\
\text { tidak melakukan } \\
\text { tindakan kriminal }\end{array}$ & 42 & 6 & 20 & 7 & 8 & 1 & 14,3 & 47,6 & 16,7 & 19,0 & 2,4 \\
\hline $\begin{array}{l}\text { Saya sebagai pegawai } \\
\text { pada unit kerja saya } \\
\text { melakukan skala } \\
\text { prioritas }\end{array}$ & 43 & 16 & 20 & 3 & 3 & 0 & 38,1 & 47,6 & 7,1 & 7,1 & 0,0 \\
\hline $\begin{array}{l}\text { Saya sebagai pegawai } \\
\text { pada unit kerja saya } \\
\text { selalu menepati janji } \\
\text { kepada pengguna jasa }\end{array}$ & 44 & 10 & 23 & 6 & 3 & 0 & 23,8 & 54,8 & 14,3 & 7,1 & 0,0 \\
\hline $\begin{array}{l}\text { Saya sebagai pegawai } \\
\text { pada unit kerja saya } \\
\text { dapat mengendalikan } \\
\text { keinginan saya }\end{array}$ & 45 & 7 & 19 & 16 & 0 & 0 & 16,7 & 45,2 & 38,1 & 0,0 & 0,0 \\
\hline $\begin{array}{l}\text { Saya sebagai pegawai } \\
\text { pada unit kerja saya } \\
\text { menggunakan dana se } \\
\text { efisien dan seefektif } \\
\text { mungkin }\end{array}$ & 46 & 9 & 30 & 3 & 0 & 0 & 21,4 & 71,4 & 7,2 & 0,0 & 0,0 \\
\hline $\begin{array}{l}\text { Saya sebagai pegawai } \\
\text { pada unit kerja saya } \\
\text { tidak menghambat } \\
\text { kebijakan pimpinan }\end{array}$ & 47 & 11 & 30 & 1 & 0 & 0 & 26,2 & 71,4 & 2,4 & 0,0 & 0,0 \\
\hline $\begin{array}{l}\text { Saya sebagai pegawai } \\
\text { pada unit kerja saya } \\
\text { tidak mengambil } \\
\text { sesuatu yang bukan } \\
\text { hak saya }\end{array}$ & 48 & 15 & 20 & 5 & 0 & 0 & 35,7 & 52,4 & 11,9 & 0,0 & 0,0 \\
\hline
\end{tabular}

Sumber: Data hasil penelitian yang diolah, (2017)

Namun masih ada $16,7 \%$ responden pegawai yang bersikap netral dan 19,0\% responden pegawai menyatakan sikap tidak setuju serta $2,4 \%$ responden pegawai menyatakan sikap sangat tidak setuju yang berarti dalam hal ini masih ada pegawai yang masih melakukan korupsi yang karena disebabkan keengganannya dalam melaporkan kekayaan yang mereka miliki. 


\section{Selanjutnya $38,1 \%$ responden} pegawai sangat setuju akan pernyataan bahwa pegawai tidak melakukan tindak kriminal dan $47,6 \%$ responden pegawai menyatakan sikap setuju yang berarti bahwa pegawai di lingkungan kantor pertanahan kota Cimahi sudah tidak melakukan tindakan kriminal, namun 7,1\% responden pegawai menyatakan bersikap netral dan $7,1 \%$ responden pegawai menyatakan sikap tidak setuju akan hal tersebut hal ini berarti terkadang masih ada pegawai yang masih melakukan tindakan kriminal dilingkungan kantor BPN kota Cimahi.

Pernyataan pegawai menepati janji kepada pengguna jasa responden pegawai menyatakan sikap sangat setuju dan 54,8\% responden pegawai menyatakan sikap setuju, yang berarti bahwa pegawai dilingkungan kantor pertanahan kota Cimahi tidak melakukan penipuan kepada pengguna jasa layanan yang diminta oleh masyarakat, namun masih ada 14,3\% responden pegawai menyatakan netral dan $7,1 \%$ responden pegawai menyatakan tidak setuju yang dalam hal ini masih ada pegawai dilingkungan pertanahan kota Cimahi masih melakukan penipuan terhadap pengguna jasa yang diminta oleh masyarakat.

Selanjutnya $\quad 16,7 \%$ responden pegawai sangat setuju akan pernyataan pegawai dapat mengendalikan keingginannya dan $45 \%$ responden pegawai menyatakan sikap setuju yang berarti bahwa pegawai dilingkungan kantor pertanahan kota Cimahi sudah bisa menggendalikan keingginan untuk tidak kleptokrasi, namun $38,1 \%$ responden pegawai menyatakan sikap netral yang berarti terkadang masih ada saja pegawai di lingkungan kantor pertanahan kota Cimahi yang tidak bisa menahan keingginannya dalam hal mendapatkan sesuatu. Copyright (C) 2019, Publik (Jurnal Ilmu Administrasi), ISSN: 2301-573X (Print), ISSN: 2581-2084 (Online)
Pernyataan pegawai menggunakan dana seefektif dan seefisien mungkin responden pegawai menyatkan sikap $21,4 \%$ sangat setuju dan $71,4 \%$ responden pegawai menyatakan sikap setuju dalam hal ini berarti pegawai dilingkungan kantor pertanahan kota Cimahi sudah cukup baik dalam hal penggunaan dana yang sesuai dengan kegunaannya, namun $7,2 \%$ reponden pegawai menyatakan sikap netral yang berarti dalam hal ini masih ada pegawai yang melakukan kontrak fiktif dilingkungan kantor pertanahan kota Cimahi.

Selanjutnya $26,2 \%$ responden pegawai sangat setuju akan pernyataan yang menyatakan bahwa pegawai tidak menghambat kebijakan pimpinan $71,4 \%$ responden pegawai menyatakan sikap setuju terhadap pernyataan tersebut yang berarti pegawai di lingkungan kantor pertanahan kota Cimahi tidak menghambat kebijakan pimpinan dan tidak melakukan sabotase, namun masih ada 2,4\% responden pegawai yang menyatakan sikap netral dalam hal ini masih ada pegawai yang menghambat kebijakan pimpinan dengan cara melakukan sabotase di lingkungan kantor pertanahan kota Cimahi.

Berikutnya $\quad 35,7 \%$ responden pegawai menyatakan sangat setuju pada pernyataan bahwa pegawai tidak mengambil sesuatu yang bukan miliknya dan $52,4 \%$ responden pegawai menyatakan sikap setuju yang berarti bahwa pegawai dilingkungan kantor pertanahan kota Cimahi tidak melakukan pencurian yang bukan haknya, namun masih ada 11,9\% responden pegawai menyatakan bersikap netral yang berarti masih ada pegawai dilingkungan kantor pertanahan kota Cimahi yang masih melakukan perncurian yang bukan haknya terhadap pengguna jasa maupun di lingkungannya sendiri.

Untuk karatersitik ini sudah sangat minimal dalam hal tindakan yang 
dilakukan oleh pegawai dilingkungan kantor pertanahan kota Cimahi, walaupun masih saja oknum yang melakukan karakteristik patologi diatas.

Telah dimaklumi bahwa setiap negara dewasa ini mengaku suatu negara berdasarkan hukum dan bukan berdasarkan kekuasaan. Artinya roda negara dikendalikan berdasarkan seperangkat ketentuan hukum yang sifatnya normatif dan setiap orang terikat dan harus tunduk pada peraturan perundang-undangan yang berlaku, dan kepada berbagai ketentuan formal lainnya yang dikeluarkan oleh para pejabat yang berwenang.

Karena hakikat peranan, kedudukan dan fungsinya para anggota birokrasi pemerintahan dikantor pertanahan kota Cimahi dituntut taat kepada semua ketentuan perundang-undangan yang berlaku secara umum. Bahkan sesungguhnya tuntutan ketaatan itu lebih berat bagi para pegawai negeri karena disamping harus taat pada semua peraturan perundang-undangan yang berlaku secara umum, mereka harus tunduk dan taat kepada berbagai peraturan yang berlaku khusus bagi pegawai negeri. Dengan perkataan lain, para anggota birokrasi benar-benar menyelengarakan fungsi dan memainkan peranannya dengan baik, harus dihindari tindakan yang dapat dikategorikan sebagai tindakan melanggar hukum. Berikut berbagai tindakan yang terjadi dilingkungan kantor pertanahan kota Cimahi, diantaranya:

\section{Menerima sogok}

Salah satu tindakan melanggar hukum yang paling mencolok dilakukan oleh pegawai dilingkungan kantor pertanahan kota Cimahi adalah menerima uang sogok. Praktek tidak terpuji ini dapat dilakukan oleh pegawai yang memangku jabatan pimpinan, tetapi dapat pula oleh para pegawai rendahan biasanya motivasi berbuat demikian adalah memperkaya diri sendiri dengan melakukan atau tidak melakukan sesuatu, untuk memperoleh imbalan financial dari pihak lain yang memperoleh keuntungan tertentu dari tindakan pejabat atau pegawai yang bersangkutan.

Berikut petikan wawancara dengan ibu ita latifah menyangkut hal yang telah dikemukakan sebelumnya, ".....karena dia dibagian pelayanan jadi pikirannya setiap hari menangkapi mangsa, jadi setelah dipindahkanpun masih ada hambatan yang dia lakukan dan dari sisi SDM ya bikin malulah gitu sampa kita dikejar polisi, wartawan jadi secara pribadi buat kita juga menggangu sampai sekarang dalam hal ini juga ada."( IL, kepala urusan umum dan kepegawaian).

Kemudian pernyataan wawancara di atas diperkuat oleh bapak Yan Setiawan, “...kalau saya perhatikan perilaku yang sedikit nyeleneh gitu ya, persepsi mereka terhadap aturan dan inpretasi mereka terhadap suatu aturan contoh terhadap pendaftaran tanah ada celah-celah yang diterobos pemohon sehingga menjadi peluang juga buat pegawai dan ternyata dalam permohonan ada segel yang direkayasa oleh pemohon." (YS, kepala seksi survey, pengukuran dan pemetaan).

Masalah sogok ini bersifat endemik, karena memang terbuka berbagai peluang untuk melakukannya tidak mustahil uang sogok diberikan karena sebenarnya yang bersangkutan tidak memenuhi semua persyaratan tidak mustahil untuk memperoleh sertifikat yang inginkan sehingga untuk mendapatkan sertifikat yang diinginkan dengan cara menyogok sehingga persyaratan tadi dianggap diganti dengan orang sehingga tidak diperlukan lagi sehingga memuluskan ke proses selanjutnya untuk mendapatkan sertifikat yang diinginkan yang diinginkan oleh 
pengguna jasa layanan tersebut. Sungguh banyak peluang bagi anggota birokrasi untuk menerima sogok yang jelas menerima sogok adalah merupakan tindakan amoral dan melanggar hukum karean perbuatan ini tidak boleh terjadi dilingkungan kantor pertanahan kota Cimahi.

Pencegahannya pun tidak mudah karena pembuktiannya sangat sulit, akan tetapi sulitnya pencegahannya bukan berarti bahwa praktek tercela ini tidak boleh dibiarkan berlangsung. Segala cara yang mungkin dapat ditempuh untuk mencegahnya adalah transparansi, pelaksanaan kegiatan birokrasi yang bersangkutan, pendidikan moral bagi para pegawai serta mengenakan sanksi yang berat terhadap pegawai yang terbukti melakukannya. Dalam UU Republik Indonesia No 20 tahun 2009, tentang pelayanan publik dijelaskan pada Bab II, bagian ke dua huruf $\mathrm{h}$ tentang keterbukaan dan hal tersebut diperkuat dengan Peraturan kepala Badan Pertahanan Nasional RI No 8 tahun 2011 Bab III pasal 4 hurup $\mathrm{f}$ yaitu terbuka dalam menyampaikan informasi yang sifatnya wajib dijelaskan kepada yang berkepentingan dengan keterbukaan dan transparansi dapat meminimalisir dan peberian sanksi bagi pegawai yang terbukti melanggar peraturan perundang-undangan.

\section{Korupsi}

Dapat dinyatakan secara kategorial bahwa korupsi merupakan merupakan tindakan kriminal yang dengan dalil apapun tidak dapat dibenarkan. Korupsi merupakan penyakit birokrasi yang harus diperanggi sampai keakar- akarnya. Dapat pula dinyatakan bahwa suatu pemerintahan yang bertanggung jawab tidak pernah membenarkan tindakan korupsi yang dilakukan oleh aparatnya. Memang tidak dapat dipungkiri, bahwa birokrasi manapun termasuk kantor pertanahan kota Cimahi selalu ada anggota birokrasi yang korup dan berupaya memperkaya diri sendiri melalui berbagai cara yang jelas melanggar hukum. Ironisnya ialah meskipun semua orang sepakat bahwa korupsi harus diberantas, sering terjadi kesulitan dalam pemberantasannya karena pelakunya melakukan dengan cara-cara yang canggih sehingga tindakannya yang melanggar hukum susah dilacak.

Berikut petikan wawancara yang mengindikasikan perilaku korupsi dari birokrasi,“....ada program pemerintah yang tidak boleh biaya/uang dari mulai kelurahan dan karena tidak ingin sendirian, maka biaya tersebut diberikan kepada BPN.”( KS, Kepala seksi pengaturan dan penataan pertanahan).

Dari hasil wawancara diatas menyatakan bahwa korupsi yang dilakukan tidak dilakukan secara sendiri melainkan berjama'ah sehingga bila terjadi pengauditan maka yang terkena tidak hanya sendiri tapi berkelompok.

Pernyataan diatas juga diperkuat oleh hasil wawancara dibawah ini, “....biasanya pungutan-pungutan diluar ketentuan itu biasanya menyangkut angaran kegiatan atau proyek yang didanai oleh APBN biasanya begitu."(FG, kepala sub Bagian Tata Usaha).

Selanjutnya untuk hasil penelitian dengan metode kuantitatif untuk karakteristik patologi yang timbul karena tindakan para anggota birokrasi yang melanggar norma-norma hukum dan peraturan perundang-undangan yang berlaku menghasilkan rentang nilai sebesar $=445$ dengan rentang sangat rendah menuju rendah pada beberapa indikator yang didapatkan pada tabel distribusi frekuensi masing-masing persentasenya sangat rendah dalam hal ini yang peneliti masukan hanya indikator diatas ( Pada tabel 4) $10 \%$ diantaranya adalah: penggemukan biaya, menerima sogok, Copyright (C) 2019, Publik (Jurnal Ilmu Administrasi), ISSN: 2301-573X (Print), ISSN: 2581-2084 (Online) 
penipuan, kleptokrasi, namun pada hasil penelitian diskriptif kualitatif tergambar jelas indikator yang lebih menonjol dari hasil wawancara dengan informan pegawai di lingkungan kantor BPN kota Cimahi diantaranya menerima sogok dan korupsi.

\section{Strategi Pelayanan Administrasi Pertanahan Yang dapat Meminimalisir Patologi Birokrasi melanggar Norma Hukum dan Perundang-undangan.}

Strategi penguatan peran birokrasi secara individu terkait dengan kualitas SDM dalam meminimalisir patologi birokrasi. Sumber daya manusia (SDM) dalam hal ini birokrasi pemerintahan secara individu merupakan salah satu faktor yang memiliki peran strategis dalam penyelengaraan pemerintahan atau administrasi publik. Sebagai individu, SDM birokrasi adalah penyelengaraan pemerintahan dan pembangunan dalam peningkatan kualitas pelayanan publik.

Adapun langka-langka yang dapat diambil adalah mulai dari perencanaan, rekruitmen seleksi, penempatan sementara, penempatan tetap, penentuan sistem imbalan, perencanaan dan pembinaan karier, peningkatan pengetahuan dan keterampilan, pemutusan hubungan kerja dan audit kepegawaian ini semua perlu dilakukan agar pegawai dilingkungan kantor pertanahan kota Cimahi dapat meniti karir dan menambah ilmu pengetahuan serta mendapatkan pelatihan, tidak seperti sekarang ini yang jarang sekali ada pendidikan dan latihan dilingkungan kantor pertanahan sehingga dapat meningkatkan kemampuan dari pegawai di kantor pertanahan kota Cimahi itu sendiri.

Agar sumber daya manusia dapat menunjukkan "daya yang lebih" maka perlu adanya model pemberdayaan seperti; pemberian peran, penempatan dalam jabatan, motivasi pimpinan, menghubungkan tanggung jawab dan menumbuhkembangkan budaya organisasi yang kondusif untuk meningkatkan kinerja organisasi. Dalam hubungan pemberdayaan sumber daya manusia, juga diperlukan pengembangan strategi yang tepat, yaitu: inward looking, outward looking, dan mengembangkan kemitraan. Pemberdayaan sumber daya manusia dimaksud, diimplementasikan pada organisasi melalui pemberian kewenangan yang jelas, pengembangan kompetensi, pengembangan kepercayaan, pemanfaatan peluang, pemberian tanggung jawab, dan pengembangan budaya organisasi. Dengan menggunakan System Model yaitu: Anticipating (antisipasi); Organisasi terlebih dahulu menentukan manajemen sumber daya manusianya. Sistem ini harus dapat mengantisipasi kemungkinankemungkinan di masa depan, mampu mengindikasikan kecenderungan terbaru dan mengembangkan program-program yang dapat memenuhi perubahan kondisi; Atracting (penarikan); Organisasi mulai memusatkan perhatian pada aktivitas yang ditujukan untuk meyakinkan bahwa organisasi mampu mencari orang-orang yang sesuai dengan kualifikasi yang dibutuhkan, diantaranya meliputi analisis jabatan, penarikan, seleksi, yang didahului oleh issu legal yang berkaitan dengan penerimaan pegawai, yaitu Equal Employment Opportunity (EEO); Developing (pengembangan); Setelah organisasi mencari dan menemukan orang yang sesuai dengan kualifikasi yang dibutuhkan, maka selanjutnya diikuti dengan pengembangan agar dapat menunjukkan kinerja yang tinggi. Upaya ini dimaksudkan dapat diperoleh dengan melalui pelatihan dan pengembangan pegawai, baik pada tingkat manajer maupun pada tingkat bawahan.Termasuk 


\section{Available Online at http://journal.umgo.ac.id/index.php/Publik \\ Publik (Jurnal Ilmu Administrasi) Vol 8 (2), December 2019}

dalam aktivitas ini adalah penilaian kinerja pegawai, pelatihan, pengembangan organisasi dan pengembangan karier; Motivating (memotivasi); Motivasi perlu dilakukan agar mereka bekerja dengan baik, sehingga menghasilkan kinerja yang tinggi. Untuk itu haruslah diketahui bagaimana cara memotivasi pegawai yang ada, misalnya dengan 157ystem konmpensasi yang berfungsi untuk memotivasi pegawai, seperti; gaji, insentif, dan berbagai program keterlibatan pegawai; Maintaining (memelihara); Aktivitas ini harus diikuti dengan adanya komunikasi yang terbuka sebagai alat utama dalam memelihara hubungan dengan pegawai yang efektif. Hubungan pegawai merupakan faktor penting karena akan mempengaruhi berbagai aktivitas SDM; Changing for Success (perubahan untuk sukses); Dalam kondisi lingkungan yang terus berubah, manajemen sumber daya manusia memberikan pendekatan untuk mengembangkan strategi-strategi baru, yakni mengadakan perubahan budaya organisasi dan mengelola keragaman SDM. Aktivitas ini akan menjadi pengkajian ulang struktur organisasi, budaya dan proses manajerial, mengelola perubahan sikap, nilai dan prosedur sehubungan dengan keragaman SDM; Focusing (pemfokusan); Mengukur efektifitas SDM dapat dilakukan dengan mengevaluasi sejauhmana efektivitas SDM dilakukan dalam organisasi. Berbagai alat dapat digunakan, mulai dari survey tentang sikap pegawai sampai dengan formal audit SDM.

Bila strategi yang telah diuraikan tersebut dilaksanakan dengan baik serta penguatan birokrasi secara individu ini dapat meminimalisir beberapa patologi birokrasi yang diakibatkan oleh SDM yang kurang profesional diantaranya patologi yang disebabkan oleh masalah berjalan sebagaimana mestinya peran

pengetahuan dan keterampilan, patologi birokrasi yang dikaitkan dengan keperilakuan.

Strategi penguatan peran birokrasi secara organisasi dalam rangka meminimalisir patologi birokrasi. Strategi yang dapat dilakukan dalam penguatan peran administrasi publik dapat dilakukan dengan empat pendekatan, yaitu: Pendekatan struktural yang penekannya menitik beratkan pada struktur organisasi, terutama perubahan struktur kelembagaan organisasi; Pendekatan teknologi, yang terfokus pada tata letak sarana fisik yang baru. Penekannnya pada penggunaan dan pemanfaatan sarana dan prasarana/ teknologi dalam melaksanakan pekerjaan (tugas dan fungsi); Pendekatan tugas (task approach), berfokus pada kinerja ( job performance) individual dengan menekankan pada perubahan dan peningkatan kinerja melalui prosedur kerja yang efektif; Pendekatan orang (people approach), berfokus pada modifikasi terhadap sikap, motivasi, perilaku, keahlian yang dicapai melalui program trainning, prosedur seleksi atau perlengkapan yang baru.

Strategi penguatan peran birokrasi secara kesisteman dalam rangka meminimalisir patologi birokrasi. Strategi yang dapat dikembangkan untuk memperkuat strategi sistem dalam meminimalisir patologi birokrasi adalah sistem administrasi pelayanan prima pola layanan satu atap. Strategi pelayanan satu atap atau sering disebut sebagai layanan terpadu pada kantor pertanahan kota cimahi agar dapat meminimalisir patologi birokrasi yang terjadi di kantor pertanahan kota cimahi.

\section{PENUTUUP}

\section{Kesimpulan}

Patologi yang timbul karena tindakan para anggota birokrasi yang Copyright () 2019, Publik (Jurnal Ilmu Administrasi), ISSN: 2301-573X (Print), ISSN: 2581-2084 (Online) 
melanggar norma-norma hukum dan peraturan perundang-undangan yang berlaku dan pada penyakit jenis ini biasanya dikarenakan keinginan mendapatkan uang lebih, ini biasanya terjadi disebabkan oleh pihak baik masyarakat ataupun birokrat, misalnya dengan cara memberikan sogok, sehingga bila persyaratan yang kurang dapat diganti dengan uang.

\section{Saran}

Strategi penguatan peran birokrasi secara individu terkait dengan kualitas SDM dalam hal ini birokrasi dalam meminimalisir patologi birokrasi; Strategi penguatan peran birokrasi secara organisasi dilakukan dengan cara melalui empat pendekatan antara lain: pendekatan struktural, pendekatan teknologi, pendekatan tugas, pendekatan orang; Strategi penguatan birokrasi secara kesisteman dalam meminimalisir patologi birokrasi adalah sistem administrasi pelayanan prima pola layanan satu atap; Dari ketiga strategi ini masih belum lengkap seharusnya ditambahkan partisipatif dari masyarakat pengguna layanan dimana masyarakat sebagai kontrol atas pelayanan yang diberikan oleh pemerintah dan apabila ada hal yang dirasakan tidak sesuai dan mungkin juga yang bersifat patologi, maka masyarakat dapat menyampaikan aspirasinya tentang pelayanan yang diberikan, sehingga tetap ada kontrol dalam pelayanan yang di lakukan oleh masyarakat sebagai pihak yang dilayani.

\section{DAFTAR PUSTAKA}

Anggraini. (2014). Menciptakan Sistem Pelayanan Publik yang baik: Strategi reformasi Dalam Pemberantasan korupsi. Jurnal Rechts Vinding. 417-433
Andrianto, Nico. (2007). Good EGovernment: Transparansi dan Akuntabilitas Publik Melalui E.Governement. Malang: Bayu Media Publishing.

Creswell. (2009). Qualitative, Quantitative, and Mixed Method Aproaches. Thousand Oaks California: SAGE Publications.

Hamirul, H. (2017). Patologi yang dimanifestasikan dalam perilaku birokrat yang bersifat disfungsional. Otoritas.14-18

Hamirul, H. (2018). The Pathology Of Public Service In The Industrial Revolution Era 4.0. Jurnal Ilmiah Tata Sejuta Mataram, 1-16.

Hamirul,H. (2019). Akuntabilitas lembaga Pemerintah Daerah Dalam Rangka Mencegah Patologi Birokrasi, Jurnal Tata Sejuta Mataram. 1-23

Hamirul. H. dkk (2018) Profesionalisme Aparatur Sipil Negara Dalam Rangka Mengatasi Patologi Pelayanan Publik. Jurnal Marketing, 133-148.

Hamirul. H. (2019). Transparansi Penggunaan Dana Desa Dalam Rangka Meminimalisir Patologi Administrasi. Jurnal Akuntansi dan Ekonomi, 68-76

Haryanto (2007). Upaya menciptakan Birokrasi yang efisien, Inovatif, Responsif dan Akuntabel. Jurnal Ekonomi dan kewirausahaan, 160171

Rivai, A. (2013). Budaya kerja Birokrasi Pemerintah Dalam Pelayanan Publik. Academica, 949-956.

Satriadin, Z. U. (2017). Pencegahan Patologi Birokrasi Melalui Reformasi Administrasi Pelayanan 
Publik. Jurnal Administrasi Negara, 157-169.

Siagian, S. P. (1994). Patologi Birokrasi: Analisis, Identifikasi dan Terapannya. Jakarta: PT Ghalia.

Ulhak, Zia dan Arif Satriadin (2017). Pencegahan Patologi Birokrasi melalui Reformasi Administrasi Pelayanan Publik. Jurnal Administrasi Negara. 134-146

Usman, Jaelani. (2016). Patologi Birokrasi Dalam Kualitas Pelayanan Uji Berkala kendaraan Dinas Perhubungan Kabupaten Takalar, Jurnal Kolaborasi, 77-90.

Yunus, S. P. (2002). Masalah Patologi Birokrasi ( Hipocracy) dan terapinya. Hukum dan Pembangunan, 144-154. 